Revista Brasileira de Odontologia Legal - RBOL

\title{
Bitemark
}

\section{UNIQUE OR NOT UNIQUE? THAT IS THE QUESTION! - OPINION ARTICLE ON A BITEMARK SCOPE}

\section{Única ou não? Esta é a questão! - Artigo de opinião voltado às marcas de mordida}

\author{
Ademir Franco ${ }^{1,2}$ \\ 1. Department of Oral Health Sciences - Forensic Dentistry, KU Leuven and Dentistry, University Hospitals Leuven, \\ Belgium. \\ 2. Department of Stomatology, School of Health and Biosciences, Pontifícia Universidade Católica do Paraná, Brazil. \\ Informação sobre o artigo \\ Recebido: 25 Nov 2015 \\ Aceito em: 11 Jan 2016 \\ Autor para correspondência \\ Ademir Franco \\ Department of Oral Health Sciences - Forensic Dentistry \\ KU Leuven and Dentistry, University Hospitals Leuven \\ Kapucijnenvoer 7, block B \\ 3000 Leuven, Belgium \\ Phone: 0032475295604 / 00554199771213 \\ E-mail: franco.gat@gmail.com
}

\section{RESUMO}

Introdução: a unicidade da dentição humana tornou-se um dos mais polêmicos tópicos das Ciências Forenses. Várias convicções fundamentadas em análises equivocadas de marcas de mordida condenaram pessoas à prisão por crimes que não cometeram. Estes equívocos tornaram-se mais evidentes ao passo que análises retrospectivas de DNA foram realizadas. Alguns inocentes foram mantidos presos por até 25 anos, e a tendência às condenações injustas aparentemente aumenta com o tempo. Objetivo: apresentar uma opinião forense baseada em evidência científica disponível na literatura atual. Conclusão: a unicidade da dentição humana relacionada a marcas de mordida continua a ser motivo de incerteza, que combinado à má interpretação técnica culmina perigosamente contra a sociedade. Novos estudos na área são altamente incentivados para testar cientificamente a existência de unicidade na dentição humana relacionada a marcas de mordida, evidenciando a real aplicabilidade desta ferramenta odontolegal.

\section{PALAVRAS-CHAVE}

Odontologia Legal, Dentição, Morfologia, Marca de mordida. 
UNIQUENESS...

"Uniqueness" is a noun derived from the adjective "unique", which became part of the English language in the beginning of the $17^{\text {th }}$ century -meaning "having no equal"1. Currently, "unique" maintained similar interpretation being defined as "not typical"1, "unusual"1, "the only existing one of its type"2, and "unlike anything else"3. Interestingly, internet searches for the definition of "unique" revealed strong relation with other nouns, such as "individuality" and "identity". "Individuality" denotes the "quality that makes a person different from the other people"2, while "identity" denotes "who a person is" 2 . In this context, "uniqueness" may be interpreted as the unusual quality inside "individuality" that indicates "who a person is".

Ancient registers of time record the earliest attempts of human individualization, such as the hand prints on cave walls performed by the primitive humans ${ }^{4,5}$. Further on, individualization became used in the civil and criminal environments ${ }^{6}$. Whereas the societies evolved within major organization, the need for social differentiation became more evident ${ }^{4}$. Despite enabling to differentiate persons within a population, the individualization process did not provide detailed information about a specific person, making necessary to find not only the "quality that makes a person different", but yet "who a person is". Thus, the spotlight moved from "individuality" to "identity". Consequently, the need for identification replaced the need for individualization.

The human identification process is mainly based on the analysis of morphological traits. An important milestone of this process dates from 1885, when Alphonse Bertillon made efforts to search for uniqueness into anthropometric information for identification purposes $^{7,8}$. Human identification evolved over the time, becoming a multidisciplinary field in forensic sciences. Consequently, the search for uniqueness varied within several techniques, such as the analyses of fingerprints ${ }^{5}$, DNA $^{9}$ and dentitions ${ }^{9}$.

\section{... OF THE HUMAN DENTITION}

Based on the previous terms, the combination of "uniqueness" and "human dentition" denotes "the only 
existing human dentition of its type". Consequently, a unique dentition would serve as an effective pathway to find out "who a person is". In Forensic Odontology, human identification may be performed both in the deceased and the living ${ }^{9}$. The first mainly concerns the identification of unknown bodies and skeletal remains, in which uniqueness may be assessed considering an enormous range of possible combinations between dental identifiers ${ }^{9}$. These dental identifiers mostly involve treatment interventions; morphological traits; and pathologies ${ }^{10}$. In general, the identification procedure is performed on a comparative basis matching ante-mortem and post-mortem dental data ${ }^{10}$. Yet the second mainly concerns the identification of potential perpetrators (suspects) of bitemark injuries, in which uniqueness may be assessed based on the combination of morphological dental traits, such as shape; size; angulation and position, found within the suspect's dentition ${ }^{11}$. In this scenario, the identification process is often performed matching the bitemark pattern with the suspect's dental impressions ${ }^{12}$. In both situations identifications may vary from exclusive to positive. However, the bitemark environment has revealed controversial outcomes in the last decades.

\section{SOCIAL IMPACT}

The reliability of bitemark evidences strongly decreased in the last decades. Recently, this branch of Forensic Odontology became questioned in the courts based on several convictions founded on the presumed uniqueness of the human dentition ${ }^{11}$. Considering that bitemark evidences usually contain the impression of the six anterior teeth $^{11}$; and only the morphology of these teeth comprehend the available dental identifiers, the number of possible combinations that support the identification process is considerably reduced potentially causing false positive dental uniqueness.

Specialized organizations indicate that several innocent people were exonerated after serving up to 25 years in prison, just in United States $^{13}$. Most of these people were found innocent due to efficient legal defense and retrospective DNA analysis ${ }^{13}$. Inevitably, an increased prevalence of wrongful convictions is expected worldwide, mainly 
considering developing countries in which DNA technology may not be available. Thus, innocent people would not only be wrongly convicted, but also spend longer periods in prison.

Moreover, the bitemark evidence includes additional variables that may bias the identification outcomes, such as the necessary technical training for the analysis of patterned injuries ${ }^{12}$. Technical training directly influences bitemark analysis potentially leading to misinterpretations. Specifically, bitemark analysis is a continuous process, in which it is not only necessary to link the perpetrator's dentition to the patterned injury (technical training), but also to guarantee that no other person in the world can be linked to that pattern (uniqueness). Based on that, the scientific community started working towards the development of optimal mechanisms for bitemark analysis and the investigation of the uniqueness of the human dentition.

\section{FORENSIC SCOPE AND OPINION}

Methodological protocols set up to prove the uniqueness of the human dentition highly vary in the forensic literature. Most of the researches are designed to investigate the six anterior teeth in plaster dental casts registered both in two- (2D) and three-dimensional (3D) imaging devices. Geometric morphometrics, algorithms, and superimpositions are performed within random and stratified samples, such as orthodontically treated patients and twins. However the literature remains controversial, and as a consequence the uniqueness of the human dentition remains uncertain ${ }^{11}$.

From a technical point of view, any structures may appear identical under the naked eye. However, differences may be found deepening on the level of detail within the analysis. Considering the human dentition in bitemark analysis, only the clinically visible dental crown parts influence the dental impression on skin. It indicates that only macroscopic traits are considered when suspects and bitemarks are matched, reducing the level of morphologic detail supporting the forensic evidence. In short, a reduced level of details combined with a reduced number of available teeth (in general the six anterior teeth), and a reduced number of identifiers (only 
related to dental morphology) potentially converge to the lack of uniqueness within the human dentition.

Despite that, the uniqueness of the human dentition, and consequently the bitemark evidence, should not be disregarded from the armamentarium of Forensic Odontology, bet yet should be tested for scientific reliability.

\section{FINAL CONSIDERATIONS}

The uniqueness of the human dentition is one of the most polemic topics of forensic sciences in the last decades. Research groups all over the world are making efforts to prove the existence of the uniqueness within the human teeth in order to test the efficiency of bitemark evidence in the forensic casework. The level of magnification in which the dentitions are analyzed seems to play an important part to determine if two or more dentitions have identical morphology or not. However, the reliability of bitemark evidence remains doubtful in the current panorama, encouraging further studies on the field. Apart from the researches, expertises on bitemark evidence must be carefully approached.

\section{ACKNOWLEDGEMENTS}

The author would like to express gratitude to Patrick Thevissen, Guy Willems and Paulo Henrique Couto Souza for supervising and promoting the doctoral project, from which the present article is part of.

The author would like to express gratitude to the Coordination for the Improvement of Higher Education Personnel (CAPES) for funding the related doctoral project.

\begin{abstract}
Introduction: The uniqueness of the human dentition became one of the most polemic topics of forensic sciences. Several convictions founded on wrongly performed bitemark analysis condemned people to prison for crimes they did not commit. Exonerations were necessary after DNA analysis confirmed the technical mistakes. Some innocents remained in prison up to 25 years, and the trend of wrongful convictions apparently increases over the time. Objective: To present a forensic opinion based on the scientific evidence available in the current literature. Conclusion: The uniqueness of the human dentition remains a matter of doubt, which combined
\end{abstract}


with misinterpreted bitemark evidence culminates dangerously impacting the society. Further studies in the field are highly encouraged to scientifically test the existence of uniqueness in the human dentition, confirming or not bitemark analysis as part of the toolbox in Forensic Odontology.

\section{KEYWORDS}

Forensic Dentistry. Dentition; Morphology; Bitemark.

\section{REFERENCES}

1. Unique. Thesaurus [online dictionary]. Available at: http://thesaurus.com [visited on Jun $11^{\text {th }}$ 2015].

2. Unique. Cambridge Dictionaries Online [online dictionary]. Available at: http://dictionary.cambridge.org [visited on Jun $11^{\text {th }} 2015$ ].

3. Unique. Oxford Dictionaries [online dictionary]. Available at: http://www.oxforddictionaries.com [visited on: Jul $11^{\text {th }} 2015$ ].

4. Wichnieski $C$, Franco $A$, Ignácio $S A$, Batista BS. Comparative analysis between dactyloscopy and rugoscopy. J Morphol Sci. 2012; 29(3); 174-7.

5. Perandréa CA, Perandrea Junior CA. Datiloscopia. Londrina: GE Idealiza; 2006.

6. Rennison CM, Dodge M. Introduction to criminal justice. Thousand Oaks: SAGE Publications; 2015.

7. Maguire M. The birth of biometric security. Anthropology Today. 2009; 25(2): 9-15.

8. Bertillon A. Identification anthropométric: Instructions signalétiques. Paris: Imprimiere Administrative; 1893.
9. Senn DR, Weems A. Manual of forensic odontology. $5^{\text {th }}$ ed. Boca Raton: CRC Press; 2013.

10. Franco A, Thevissen $P$, Coudyzer W, Develter W, Van de Voorde W, Oyen R, Vandermeulen D, Willems G, Jacobs R. Feasibility and validation of virtual autopsy for human identification using Interpol dental codes. J Forensic Leg Med. 2013; 20(4): 248-54. [doi: 10.1016/j.jflm.2012.09.021].

11. Franco A, Willems G, Souza PHC, Bekkering GE, Thevissen. The uniqueness of the human dentition as forensic evidence: a systematic review on the technological methodology. In J Leg Med. 2014; 129(6): 1277-83 [doi: 10.1007/s00414-014-1109-7].

12. Johansen RJ, Bowers CM. Digital analysis of bite mark and human identification. Dent Clin Noth Am. 2001; 45(2): 327-42.

13. Bitemark evidence deemed unreliable. The Innocence Project [online website]. Available at: http://www.innocenceproject.org/newsevents-exonerations/bite-markevidence-deemed-unreliable [visited on: Jul 11th 2015]. 